\title{
Ends and Beginnings
}

\author{
Rebuilding the Big Screen
}

In 1981, UNESCO reported that the vast majority of Nigeria's imported films-a whopping 86 percent-came from the United States. ${ }^{1}$ The very same year, Hollywood studios and the US Department of State declared Nigeria hopelessly corrupt, and the Motion Picture Association of America (MPAA) called for a boycott of cinematic trade with the country. However compromised, the "new spirit of economic nationalism and self-reliance" that had emerged in Nigeria amid the oil boom of the 1970s, bolstered as it had been "by the swing to the left in Nigerian politics, and by a marked distrust of foreigners," formed part of the boycott's backstory. ${ }^{2}$ When the MPAA announced its boycott, Nigeria was under civilian president and former finance minister Shehu Shagari, whose Economic Stabilization Program prescribed the limiting of import licenses and the raising of customs duties-one of several policies that proved off-putting to Hollywood amid the global inflation of the 1970 and a general profit squeeze.

Yet rather than exposing Nigeria's pathological status on the world stage, the MPAA's 1981 call for member studios to retreat from the country merely exemplified how, in "the neoliberal vision of world order, the world economy exercises discipline on individual nations through ... the flight of investment that punishes expansion in social policy," as Quinn Slobodian puts it. ${ }^{3}$ There can be no doubt but that Hollywood benefited from the thirty or so fully licensed cinemas that operated in Lagos alone during the oil boom, when local exhibitors could afford the exorbitant rental fees imposed by the MPAA. Falling oil prices, coupled with Shagari's strategic refusal to submit to conditions outlined by the International Monetary Fund (IMF), changed all of that-at least temporarily. ${ }^{4}$

At the very moment at which the Nigerian state, in its relatively brief configuration as Shagari's ostensibly civilian Second Republic, began to pursue concrete protectionist strategies aimed at curbing Hollywood's local influence and limiting 
its capacity to profit, the MPAA, which has always enjoyed the cooperation of the US Department of Commerce, was beginning to more openly embrace neoliberalism as a specific (and rapidly consolidating) brand of market orthodoxy. ${ }^{5}$ Robert Pollin identifies 1980 as "the most appropriate point to mark the transition out of the post-World War II era of developmental state policies and the ascendancy of neoliberalism." It is perhaps fitting, then, that the neoliberal era, as periodized by Pollin, began with the MPAA's attempt to punish Nigeria for its resistance to the wildly asymmetrical terms on which Hollywood had always conducted business in the country. ${ }^{7}$ In keeping with broader neoliberal efforts to turn Nigeria into a (more) development-friendly free-trade state, the MPAA called upon member studios-precisely those companies that Eric Johnston had, two decades earlier, urged to enter so "accommodating" a country-to finally abandon Lagos. That they did, and not in defeat but in disgust, conveniently citing "corruption," is an indication of the sheer force of the MPAA's commitment to the neoliberal economic order from which Shagari's Nigeria was seen as deviating. ${ }^{8}$

The association's hardline position was not without precedent. In the early 1960s, for example, Cinestar International, an American movie company doing business in Nigeria, drew up a contract that gave it the unrestricted right to terminate its dealings in whole or in part, and without liability, in the event of, among other "happenings": "the enactment or promulgation of any import regulation restriction, quota or embargo affecting the importation of motion picture films or the enactment or promulgation of any censor or any internal regulation affecting their exhibition or distribution"; "the imposition of any burden or restriction upon foreign exchange or the imposition of any import duty, tax, fee or other fiscal charge affecting foreign motion picture films"; and "any measure or action taken or authorized to be taken by any public official in the territory ... prohibiting or tending to prohibit the exhibition or distribution of any . . f films of Cinestar." When the company finally fled Nigeria, however, it was in response to the Biafran Civil War. Cinestar, whose patented plastic-and-nylon CineDomes were obvious targets, had listed "war or public disorders" among its litany of causes for contract termination. The Biafran conflict simply represented too big a risk. ${ }^{10}$

\section{DISNEY'S “NIGERIA PROBLEM”}

As the case of Cinestar suggests, American film history is hardly reducible to the activities of the major Hollywood companies. United Artists might have closed its Nigerian offices in response to the Biafran Civil War, but other firms, including those not primarily associated with cinema, continued to use moving images to help expand their corporate footprints in and around Lagos. Even in the late 1970s, these US firms, buoyed by soaring profits, increased their commitment to the production, distribution, and exhibition of films in Nigeria. They included Fisher Scientific, a Pittsburgh-based laboratory supply and biotechnology company that 
in 1972 achieved sales of $\$ 8.1$ million in Nigeria as a result of a hospital-equipment trade mission organized by the US Department of Commerce. In the spring of 1976, US Secretary of State Henry Kissinger directed the American Embassy in Lagos to participate in Fisher's production of short films "on [the] company's success story" - cinematic testimonials to Nigeria's lasting economic value. ${ }^{11}$

A few months later, Nigeria's Capital Development Authority, an entity concerned with the municipal development of Lagos, sent a special fact-finding mission to the United States. The mission visited, among other sites, Disneyland in California, and it later spent two days at Disney World in Florida. (The latter park had opened just five years earlier, in 1971.) The mission's goal was to study urban and regional planning and, in particular, to scrutinize Disney's approach to yearround land care and management. ${ }^{12}$ From Disney's perspective, however, the trip was not a success. A proposed deal with the conglomerate had "fallen through, with Disney World authorities and the [US] Department [of State] left holding the bag." Members of the mission reportedly adopted their own, idiosyncratic approach to studying Disney, and-much to the conglomerate's chagrin-they did so without any official supervision. Learning of Disney's displeasure, a Nigerian diplomat retorted that, "after all, Disney World was not one of [the Capital Development Authority's] priorities." ${ }^{3}$ The conflict-Disney's very own "Nigeria problem"-illustrates Janet Wasko's claim that the alleged "universality" of the Disney brand "is neither automatic nor natural, but has been, and continues to be, deliberately manufactured and carefully controlled." ${ }^{14}$ As a source of defiant developers and flippant diplomats dismissive of the conglomerate's determination to achieve world domination, Nigeria represented, in the late 1970s, one of Disney's biggest obstacles.

Disney was not deterred, however. It persisted, even at a time of global economic crisis, in seeing Nigeria as a potential player in the international proliferation of its theme parks. ${ }^{15}$ In early 1979, a team of Imagineers traveled to Nigeria as part of the Disney World Showcase Project, a global initiative to link "local cultures" to the Disney brand. ${ }^{16}$ Echoing the French colonial politique indigene- "the conceit that a new policy that paternalistically respected indigenous cultures was essential to lead the natives into progress"-the Imagineers sought, paradoxically, to preserve local "cultural attractions" in the modernizing idiom of Disney, gaining permanent corporate footholds in the process. ${ }^{17}$ (Cinestar, with its patented Multitrax projection system designed to serve the needs of multilingual Nigerians, was perhaps another inspiration for Disney.) Nigeria, where pirate cinemas were already beginning to vastly outnumber "legitimate" movie theaters by the end of the 1970s, proved particularly challenging to a project that required major exhibition venues, places in which to showcase Disney's support for indigenous achievements. In response to Nigeria's infrastructural shortcomings, Imagineers sought to erect their own, temporary facilities in the country. They were therefore following in the footsteps of those Cinerama representatives who had, in the early 1960 , 
demonstrated their own global "exhibition revolution" by producing Shellarama and setting up (with considerable help from Cinestar) a number of "promotional theaters" throughout southern Nigeria.

Disney's vision for a Nigerian theme park cited not only Cinerama's precedent but also Imagineering's own: in 1954, two years after Walt Disney founded it, his design and development arm oversaw a foray into the "dark continent" that culminated in "Cameras in Africa" a 1954 episode of ABC's anthology television series Disneyland. ${ }^{18}$ True to the company's imperialist goals, "Cameras in Africa" offers up the continent as (in the words of Walt Disney himself, who addresses the camera as the episode's host) "one of [the] many worlds ... open to you," the American viewer. It is Walt Disney's "personal pleasure" to "incorporate" Africa into the company's mawkish imperium. Tellingly, the continent does not belong to "Fantasyland, the happiest kingdom of them all," or even to "Frontierland" (here defined in terms of "tall tales and true from the legendary [American] past," pivoting around the persona of Davy Crockett), but to "Adventureland, the wonder world of nature's own realm."

In sharp contrast to America-and in keeping with what Thomas Hodgkin, writing in 1956, called the "Hobbesian picture of a pre-European Africa, in which there was no account of Time; no Arts; no Letters; no Society"-Africa is understood as lacking both history (it has no past, "legendary" or otherwise) and people (only wild animals are shown in "Cameras in Africa," via glimpses of the making of Disney's upcoming feature-length nature documentary The African Lion [James Algar, 1955]). ${ }^{19}$ As the host of "Cameras in Africa," Walt Disney, who points to a map of the continent while surrounded by various traditional masks and other carvings, says of the production of The African Lion, "It soon developed that we were making a picture as big as Africa itself!" What he does not mention is that the film's shooting locations were, in fact, confined to just three of the continent's countries-Kenya, Uganda, and Tanganyika. "Cameras in Africa" proceeds in much the same vein, subsuming national particularities under a "celebration" of continental vastness. Much as the episode was meant to build audience anticipation for The African Lion, Imagineering's 1979 foray into Nigeria was intended to cultivate consumers of future Disney products, including those that could be made and marketed in the country. According to the US Department of State, Disney's designs on Nigeria were clearly “in [the] interest of development of U.S. trade and tourism." ${ }^{20}$ But as a new decade dawned, Nigeria seemed anything but hospitable, and Disney backed away—albeit temporarily.

\section{HOLLYWOOD AT FESTAC}

The discourses of corruption peddled by Hollywood interests (often in collaboration with the US Departments of State and Commerce) functioned to normalize a certain alienation from Nigeria. As Steven Pierce suggests, "corruption" is 
best understood not as a specific material act but as a rhetorical tool and disciplinary strategy. "Treating it as designating something coherent and real, which states might be plagued by or not, naturalized an ideological portrait of the noncorrupt state as a European state," writes Pierce. Labeling Nigeria "corrupt," the MPAA endeavored to define standard Hollywood practice, which had always been marked by "oppressive, self-interested, accumulative, illegal actions," as not only upstanding but also the normal approach to conducting business on the global stage. ${ }^{21}$ Given corruption's association with local forms of exchange, the term's application to Nigeria served, in the context of film distribution and exhibition, to further mystify Hollywood's morally questionable actions around the world. If Hollywood was global (and thus good), and Nigeria local (and thus suspect), the latter's pursuit of fairer terms of trade could be seen as necessarily unscrupulous and self-serving-in a word, corrupt. ${ }^{22}$

Upon its establishment in 1975, the MPAA's Film Security Office, an antipiracy agency with numerous branches around the world, raised concerns about the Nigerian market, fearing the "government's desire to take in a greater share of the profits" from the exhibition of Hollywood films. ${ }^{23}$ The signs of Nigeria's growing resistance to Hollywood's trade policies were impossible to ignore by the end of the 1970s, when they began to assume a diversity of forms following the Second World Black and African Festival of Arts and Culture (FESTAC). Held in Lagos in early 1977, this "black cultural Olympics" was a source of considerable frustration for the city's residents, many of whom balked at high ticket prices and the presence of armed guards in and around the newly completed National Theatre, with its ultramodern screening rooms (fully equipped with $16 \mathrm{~mm}, 35 \mathrm{~mm}$, and $70 \mathrm{~mm}$ projectors), a closed-circuit television system, and eight interpreters' booths. ${ }^{24}$ More, perhaps, than any other development, the construction of the National Theatre-and, specifically, the facility's outfitting for FESTAC-foretold the emergence of multiplex chains in Nigeria. So, of course, did the festival's controversial inclusion of so many American films, precisely those national products that would dominate the multiplexes upon the latter's introduction in the early years of the twenty-first century. ${ }^{25}$

As a Black-minority country, the United States had to be incorporated (along with Canada) as a "Black community"- part of the North American zone-in FESTAC's complicated administrative organization. Nevertheless, American cinema would be well represented, its entries far outnumbering those of the host country. This was a rather scandalous (yet scarcely surprising) state of affairs that led the New York Times to assert in its coverage of the festival that the "film industry is still embryonic in black Africa." ${ }^{26}$ As the making of The Mark of the Hawk had demonstrated two decades earlier, the conditions for the development of a truly indigenous cinema in Nigeria were virtually nonexistent, and little had changed since 1957. But was African cinema, as a whole, really "embryonic" in the late 1970s? Certainly far more Black African films were available than were 
eventually programmed at FESTAC. With its global focus leading to a disproportionate emphasis on American cultural production, the festival would only reinforce the impression of African cinematic scarcity in the face of Hollywood excess. ${ }^{27}$ The fruits of a booming oil economy and of a related desire to project Nigeria's modernizing potential, the National Theatre's two state-of-the-art cinema halls were designed, in part, to accommodate Hollywood films. ${ }^{28}$ The first chairman of FESTAC's North American zone, Ossie Davis, began his tenure just two years after the release of his hit 1970 film Cotton Comes to Harlem (distributed by United Artists), and he helped secure private-sector support as well as funding from the US Department of State. ${ }^{29}$

FESTAC organizers actively solicited CinemaScope films and other widegauge productions associated with the major Hollywood studios. ${ }^{30}$ At the same time, they refused to consider $8 \mathrm{~mm}$ and Super 8 submissions, thus anticipating the blatantly anti-Nollywood gatekeeping strategies of later African film festivals, including FESPACO, which barred both analog and digital video formats until 2015, effectively preventing Nollywood's inclusion (and reinforcing the impression of the industry as strictly a small-screen affair). ${ }^{31}$ FESTAC's directors even went so far as to adjust the festival's two-films-per-participating-country policy in order to accommodate the prolific Hollywood studios, which were instructed to apply to the International Secretariat if they wanted to "present more [than two] films." ${ }^{2}$

Ultimately, a total of twenty-one American films, of varying relationships to studio capital, screened in the National Theatre's two air-conditioned, eight-hundred-seat cinema halls, as well as at Glover Hall (1,500 seats) and the Nigerian Institute of International Affairs (388 seats), between mid-January and mid-February $1977 .{ }^{33}$ These included films typically studied in relation to Blaxploitation and the broader Black cinema boom of the 1970s, such as Sidney Poitier's Buck and the Preacher (1972) and Uptown Saturday Night (1974); Michael Schultz's Cooley High (1975) and Car Wash (1976); Michael Campus's The Education of Sonny Carson (1974); Gordon Parks's Leadbelly (1976); and Ivan Dixon's The Spook Who Sat by the Door (1973)..$^{34}$ Many of these films were distributed by major Hollywood studios, including Paramount, Warner Bros., and Columbia. By contrast, Larry Clark's fifty-two-minute, $16 \mathrm{~mm}$ drama As Above, So Below (1973), which also screened at FESTAC, is now celebrated as an early contribution to the countercinema movement known as the L.A. Rebellion. Its presence in Lagos testifies to the dogged efforts of some of the movement's members to break into the international festival circuit. ${ }^{35}$ Along with The Spook Who Sat by the Door and the activist documentary A Luta Continua (Robert F. Van Lierop, 1973), Clark's film stands out among the FESTAC selections for its radical political and social critique. Conceivably, it countered or at least complicated the impression of Hollywood hegemony (including over Black cinematic expression) and American state support that the festival seemed largely to provide. ${ }^{36}$ 
Other American entries sat uneasily between the two poles represented by the crowd-pleasing likes of the Poitier comedies and the oppositional efforts of Clark, Dixon, and Van Lierop. Directed by Woody King, Jr., the family drama The Long Night (1976) was produced by King's own production company and, as Jonathan Munby points out, mishandled by Howard Mahler Films, "a small-time distribution company for mainly exploitation material." 37 Retitling it Steely Brown, the company gave The Long Night an extremely limited domestic release. That it ended up at FESTAC is an indication of the distributor's last-ditch efforts to see a return on its investment-a symbol of the resuscitative potential of a country where individual films, and the medium of cinema itself, have periodically been reborn. ${ }^{38}$

Unlike the more familiar festival model of compensating filmmakers with mere exposure and the possibility of a distribution deal, FESTAC was offering mainly revivals, and organizers were able to pay distributors' fees with various funds, however irregular and ill-gotten (the products of what Andrew Apter refers to as "the euphoric marriage of oil and culture"). ${ }^{39}$ It is unclear how much, say, Larry Clark was paid for As Above, So Below, or whether distributors were able to share boxoffice revenues (reportedly considerable) with the National Theatre. Such opacity derives from the general difficulty of determining FESTAC's precise expenditures, as well as who, exactly, benefitted from stolen funds, misused assets, and other unor underreported exchanges. It is, however, highly unlikely that the major studios Warner Bros. (which distributed the smash hit Uptown Saturday Night), Columbia (which distributed Buck and the Preacher), and Paramount (which distributed The Education of Sonny Carson and, controversially, Leadbelly) failed to negotiate terms favorable to them, especially given their active, coercive presence on the ground in Lagos, and the "kickbacks and corruption"- the diffuse "culture of contracting" - characteristic of FESTAC and the broader oil economy. ${ }^{40}$ What some Nigerian commentators referred to as the festival's "dirty and secret deals" almost certainly encompassed interactions with Hollywood studios well versed in such unscrupulous practices. ${ }^{41}$

What Apter calls "mercurial money forms" were central to FESTAC's organization: "the quasi-mystical character of petro-naira" reliably filled the coffers of foreign companies, including those associated with Hollywood cinema, and drove "a peculiar form of deficit production disguised by the appearance of material progress." ${ }^{2}$ Such an impression was secured, in part, not only through the National Theatre's state-of-the-art cinema halls but also through organizers' controversial and widely circulated calls for CinemaScope revivals and other reminders of Hollywood's spectacular achievements. What better way to signal Nigeria's modernity, organizers and other pro-FESTAC factions wondered, than through the fluid accommodation of heavily capitalized Hollywood films? The festival was, however, obliged to strike a delicate balance between projecting moneyed modernity (including through the screening of star-studded studio films like Uptown 
Saturday Night) and acknowledging such smaller, artisanal works as A Luta Continua and As Above, So Below. As in the ever-contentious discourses surrounding Blaxploitation, debates over Blackness were central to FESTAC's organization and implementation. The festival's "horizons of blackness" unmistakably extended to Hollywood, as oil revenues invariably fell into a wide variety of private hands, leaving some commentators to complain that, far from true champions of Black cultural production, American asset holders doing business with FESTAC were "by and large . . cold, unsympathetic and only committed to the dollar," a reality of which members of the North American zone were only too aware. ${ }^{43}$ Indeed, it was partly in response to these political-economic conditions that future filmmaker Hubert Ogunde withdrew from FESTAC, resigning from the festival's subcommittee in protest. ${ }^{44}$

The list of films screened at FESTAC should thus be seen as representing a kind of compromise between the requirements of Hollywood capital—of powerful rights holders-and the cultural aspirations of Black American artists and intellectuals. As the career of Larry Clark makes clear, the two were not necessarily one and the same. Proponents of Clark's As Above, So Below and other independently produced films faced an uphill battle against Hollywood studios, many of which enjoyed direct lines to Lagos, having long since established branch offices there. As Apter points out, films reached FESTAC "following vertical channels of national distribution rather than popular interest and demand." 45 A total of only five Nigerian films screened at FESTAC-less than a quarter of the number of American films selected. These included the documentaries God Dance, Man Dance (Frank Aig-Imoukhuede, 1975), T.B. Can Be Cured (Federal Film Division, ca. 1976), and 2,00o Years of Nigerian Art (1977), which Tunde Kuboye made while serving as head of the audiovisual section of the National Museum in Lagos. The rest of the slate comprised the historical epics Shehu Umar (Adamu Halilu, 1976), an adaptation of Tafawa Balewa's novel, and Ovonramwen Nogbaisi (ca. 1977), a filmed record of a performance of Ola Rotimi's play about the Benin Expedition of 1897, which resulted in the theft and relocation to the British Museum of the very sculptural portrait chosen as the official symbol of FESTAC. (Eddie Ugbomah's 1979 film The Mask would similarly address the "incarceration" of Black art in museums, focusing on what had come to be known as "the FESTAC mask.") ${ }^{46}$ Produced by the federal government, Shehu Umar was Nigeria's official entry for FESTAC, but the film screened only once, toward the end of the festival; even the white-directed The Education of Sonny Carson received more screenings, no doubt because it had Paramount, whose Nigerian distribution office was not far from the National Theatre, behind it. ${ }^{47}$

As the final screening list makes clear, not all of FESTAC's American films were produced beyond the ambit-that is, outside the direct creative controlof the major Hollywood studios. Many were distributed by those very studios, which benefitted both materially and symbolically from the exhibition of their 
films at the festival. Pioneering Black filmmakers like Parks and Poitier were, during this period, among the go-to "producers of content for studios that had lost their monopolistic control over the film industry." ${ }^{48}$ Donald Bogle convincingly refers to their works as "major studio films," writing, "At heart, these were escapist, nonthreatening, bourgeois yarns." 49 The presence of such films at FESTAC was enabled, in part, by the permanent distribution offices that the major Hollywood studios had established in Lagos in the early 1960s. Such branch offices served as reliable conduits not only between Hollywood and commercial theatrical exhibition in Nigeria but also, in 1977, between Hollywood and FESTAC (itself a forum for commercial theatrical exhibition, as the National Theatre's festival program and other archival documents attest).$^{50}$ Several major studios apparently saw FESTAC as an opportunity to squeeze additional profits out of films that were already hits, such as Warner Bros.' Uptown Saturday Night, or that they had mishandled domestically, such as Columbia's Buck and the Preacher and Paramount's The Education of Sonny Carson and Leadbelly. ${ }^{51}$ In at least one case, however, studio capital opted out of this remunerative process: the ailing UA, which no longer had offices in Lagos by the 1970s, had, in a much-debated move, pulled The Spook Who Sat by the Door from commercial theatrical exhibition in the United States and later relinquished all distribution rights.

This does not mean, however-as is typically assumed - that the film was withheld from legal commercial circulation for the next thirty years. ${ }^{52}$ Its resurfacing at FESTAC was, in fact, a function of the efforts of writer-producer Sam Greenlee, who, in acquiring ownership of The Spook Who Sat by the Door, also gained a new distributor, the Black-owned American Transcontinental Pictures (ATP). If (to quote Jet magazine) "a major white studio"—UA—-had mishandled the film, "a Black distributing company"-ATP_-was not only managing to "put Spook back behind theater doors" but also to turn a profit in the process. Targeting Blackowned cinemas in Memphis and Louisville, ATP also set its sights on FESTAC, booking The Spook Who Sat by the Door in the National Theatre's Cinema Hall II over three years after its US premiere-a fact that, for whatever reason, Dixon and Greenlee failed to mention in later interviews, during which they insisted that their film wasn't screened publicly for three decades after UA and the FBI allegedly destroyed all prints but Dixon's original negative. ${ }^{53}$ Ironically, Dixon had previously portrayed Nigerian student Joseph Asagai in the film adaptation of Lorraine Hansberry's play A Raisin in the Sun (Daniel Petrie, 1961), which offers a memorable endorsement of the promise of Nigerian independence. After Walter Lee Younger (Sidney Poitier) squanders his family's much-needed insurance money, his sister Beneatha (Diana Sands) complains, "He gave away my future!" It is a measure of Nigeria's midcentury potential that the film, like the play, can present the country as compensatory-as, that is, eminently capable of restoring what Beneatha has lost to her brother's misadventures. Dixon's Asagai offers the young woman a chance to start life anew in Nigeria, an opportunity that Beneatha 
seriously considers, even as she recognizes that Nigerians "need ... salvation from the foreigners on their lands."

Dixon's The Spook Who Sat by the Door was among the cinematic foreigners taking up considerable screen space at FESTAC, where all English-language films - from Poitier's Buck and the Preacher to the Nigerian government's own T.B. Can Be Cured-had to be subtitled in French. ${ }^{54}$ Favoring subtitling over dubbing, the former being the far cheaper option for distributors, the festival took an allegedly majoritarian approach to the matter of translation, favoring two widely spoken European languages and excluding all others, at least from subtitle tracks. At the level of language, then, this "black cultural Olympics" came nowhere close to what Cinestar's Multitrax system had promised to make possible for multilingual Nigerians nearly two decades earlier.

Wole Soyinka alludes to such a failure in his acidulous critique of FESTAC, which "offered a narrowed-down, reductionist aspect of culture in a gargantuan orgy of ill-organized spectacles." For Soyinka, Hollywood is implicated-as both cultural-ideological fount and political-economic formation-in "those extravagant fields of 'Festacian' revelry," on which "complex, enriching offerings were relegated to token, or symbolic, expositions, starved of funds and given scant coverage even in the media, and were finally relegated to the archives of that supracultural monstrosity known as the National Theatre." 55 Translation into more than just English and French was certainly technologically possible even for FESTAC, whose organizers had aggressively publicized the outfitting of the National Theatre (including the 1,60o seats at Cinema Halls I and II) with devices for the delivery of simultaneous translation into six languages. But it was not pursued for cinematic offerings, leading at least one critic to complain of a lack of linguistic diversity. ${ }^{56}$

While the US State Department's sponsorship of FESTAC was hardly uncontroversial (echoing The Spook Who Sat by the Door, some Nigerian newspapers even "warned that the U.S. delegation contained CIA agents who were out to 'destroy the unity of black peoples"'), it was continuous with Hollywood's general, ongoing efforts to infiltrate the Nigerian market. ${ }^{57}$ The State Department clearly understood the festival's potential significance as cultural terrain on which a Cold War battle could be fought - and, with Hollywood's help, won. Yet if the list of American films screened at FESTAC suggests an ambiguous, even blatantly contradictory collection of representational techniques - a far cry from the unequivocal anticommunism of The Mark of the Hawk and other monotonous capitalist cudgels-that is because of ongoing tensions between the State Department and the North American zonal committee. Such agitation ultimately ensured that Paramount and Warner Bros. properties would be screened alongside far less conventional works. ${ }^{58}$

Even if the major Hollywood studios had not been solidly entrenched in Lagos, they would likely still have succumbed to the impulse to exploit FESTAC, the corrupt lead-up to which, Steven Pierce argues, constituted a major inducement to foreigners to do business in Nigeria. Citing the so-called "cement armada" of 1974, 
when an oversupply of overpriced cement—half the world's stock, in fact-choked the Port of Lagos, Pierce suggests that the scandal "served as a demonstration of the possibilities available to Westerners of Nigerian corruption," catalyzing "illicit contacts between Nigerian officials and foreigners." ${ }^{59}$ Hollywood's monopolization of FESTAC screens was, however, less a measure of the legacy of the cement armada than an instance of business as usual-and neither the first nor the last example of the industry's willingness to take advantage of discourses of global Blackness in Nigeria. As Jemima Pierre points out, such discourses have long demonstrated the "significance of Africa's racialization to the articulation of modern processes," including of capital accumulation. Celebrating the "Black World" on the occasion of FESTAC, Hollywood merely "reinforced Africa's marginalization," much as it had through the earlier exploitation of decolonization (epitomized by the making of The Mark of the Hawk), and much as it would with the continental "saturation release" of Disney's Black Panther in 2018. ${ }^{60}$

\section{CREATING A “CINEMATIC WASTELAND”}

The MPAA's sanctioning of the Second Republic in 1981, just four years after FESTAC, stands as a stark reminder of what can happen when states fail to accede to Hollywood's specific demands. The Shagari administration's attempts to resist and redirect the industry's hegemony were, in part, responses to perceived fissures in the American political-economic system. As Fred L. Block puts it, "when a hegemonic power is at its height, other nations are usually respectful toward the global rules that are pushed by the hegemon. But when other nations see the great power struggling, they are more likely to find ways to work around or even directly violate the rules." ${ }^{\prime 1}$ When the Second Republic seized Hollywood assets, it was in the wake of global inflation, a global profit squeeze, and-perhaps most significantly-the Vietnamese military victory over the United States, precisely the kind of "rebel win" anticipated in A Luta Continua and other anti-imperialist films screened at FESTAC. ${ }^{62}$ A reckoning must have seemed possible.

Hollywood's subsequent estrangement from Nigeria coincided with the administrations of presidents Ronald Reagan, George H.W. Bush, and Bill Clinton, and thus with the shift from a certain style of cultural diplomacy-one that, in the name of Cold War concerns, centralized Africa as a strategic site and potential partner-to a period in which, as Penny Von Eschen points out, Africa was the source merely of a "grudging alliance" and the victim of devastating IMF-World Bank structural adjustment policies. ${ }^{63}$ Yet those very policies helped pave the way for the return of theatrical exhibition in Nigeria in the twenty-first century, facilitating various un- or under-regulated development schemes, some of them involving the direct participation of North American companies like IMAX, with its "chain of large-screen theaters that involve massive projection systems." 64 "From the Reagan era onward, American leadership was determined to reassert political 
and economic hierarchies," writes Von Eschen, and it is precisely as such a reassertion-a forceful underscoring of global terms of trade-that Hollywood's renewed attention to Nigeria's exhibition sector should be viewed. ${ }^{65}$

The relative slump in commercial theatrical exhibition that characterized the roughly twenty years between the end of the oil boom and the transition to Nigeria's Fourth Republic may have inspired the emergence of Nollywood as a paracinematic phenomenon committed to circumventing traditional media distribution streams with a straight-to-video panache. But it also cultivated an impression of Nigeria as_cinematically speaking-occupying an eccentric order of time, beyond or behind a global North increasingly dotted with opulent multiplexes. Such opulence, the worldwide establishment of ever more screens strategically linked to various practices of extracinematic consumption, has long benefited Hollywood at the expense of established and emergent national film industries. Hollywood's outsize success in Britain in the 1920s was, for example, partly attributable to the construction of "luxury picture palaces", including the two-thousand-seat Tivoli Picture Theatre on the Strand (taken over by MGM/Loews in 1925, three years before the company opened its Empire Theatre in Leicester Square), the neoclassical Capitol Theatre on the Haymarket, and Paramount's plush Plaza Theatre on Lower Regent Street. ${ }^{66}$

"The Americans, with their impressive supply of Hollywood pictures, have the necessary tank power to put native exhibitors at their mercy," read a 1937 editorial in World Film News. "They are using it remorselessly." ${ }^{67}$ Tying Hollywood's supply to the demand manufactured through the global construction of ever larger and more "attractive" theaters, the editorial rightly stressed the industry's capacity to benefit from the steady expansion of moviegoing opportunities, particularly in "developing" and "re-building" economies. In the postwar period, Hollywood's global hegemony only grew, thanks in no small measure to the IMF agenda of prying open new markets for US investors and preventing less powerful nationstates from restricting cross-border capital flows. ${ }^{68}$ Nigeria's roughly twenty-year dislocation from Hollywood expansionism has made the return of commercial theatrical exhibition - and, more specifically, the emergence of the multiplexesa cause for considerable celebration, akin, perhaps, to the return to democratic rule, with which it is historically isomorphic and through which it is so frequently metaphorized. Formal democratization and the capitalized expansion of moviegoing opportunities are thus seen as overdue developments, the well-earned rewards of a population long manacled by military rule and social unrest.

The notion that Nigeria is deserving of consumerist "upgrades," even those whose main economic beneficiaries are to be found far beyond the country's geopolitical borders, has deep roots in cultural studies. In 1958, Stuart Hall suggested that the developing world's "belated" embrace of consumer electronics constituted "a legitimate materialism, born out of centuries of physical deprivation and want." ${ }^{\prime \prime}$ Throughout the immediate postwar period, however, several left-leaning 
publications stressed the dangers of such materialism, however understandable as a response to colonial modes of dispossession, and particularly as it came to be compatible with the aims of emergent neocolonial power structures. ${ }^{70}$ The oligopolistic fields of film distribution and exhibition offered, and offer still, striking illustrations of economic and cultural asymmetries couched in the mystifying terms of a "legitimate materialism."

Another, more juridical discourse of legitimacy has further informed efforts to construct the big screen in Nigeria. The materialism of postcolonial Africans may have been perfectly legitimate (in Hall's terms), but it hardly mattered to Hollywood if it could not generate profits for the industry-if, that is, it circumvented copyright and other protections. In September 1984, a US Senate subcommittee on international copyright defended the MPAA's decision to withdraw from Nigeria, where, it contended, "copyright problems" abounded, along with "violations of territorial distribution limitations." The Nigerian state's attempt to benefit materially from the unauthorized circulation of lawfully imported films (including in "unofficial" nontheatrical venues that were beyond the scope of Hollywood's surveillance) had been a cause for considerable concern for the past several years - at least since Columbia secured a Christmas 1978 release for Steven Spielberg's Close Encounters of the Third Kind (1977) at the National Theatre in Lagos. (Prints of the Spielberg blockbuster were believed to be likely targets of piracy.) The MPAA was also, as ever, worried about the underreporting of box-office grosses (a duplicitous practice that was far from unique to exhibitors in Nigeria). ${ }^{71}$ Invoking the country's previous contributions to Hollywood profits, the 1984 Senate subcommittee went on to argue, "Nigeria is a state in which foreign copyright holders would expect to receive 'adequate and effective' protection. Yet it is a place where they do not find such protection and piracy flourishes." ${ }^{\prime 2}$

In the eyes of the MPAA, the spike in piracy that accompanied the transition to the Second Republic was coterminous with-even motivated by-the attempts of the Shagari administration to "indigenize" film distribution and exhibition. Historians have-with good reason-tended to situate these indigenization decrees among the merely symbolic and otherwise "half-hearted attempts to reorder cinema policy in independent Nigeria." ${ }^{\prime 3}$ As Hyginus Ekwuazi put it in 1987, "nothing changed-other . . . than the names of the companies. . . Essentially, the pulse has remained the same: foreign."74 As outlined by Shagari and others, the goal of indigenization "was to place 'control' of the economy in the hands of Nigerians, and ensure that they [would be] the main beneficiaries of the country's resources," which included moviegoers: ticket buyers who could, as a direct consequence of cinema spectatorship, become consumers of any number of other items. ${ }^{75}$ Indigenization is not the same as nationalization (which implies a transfer of economic ownership to the state). The former, by contrast, was, in the case of Nigeria in the 1970s and early 1980s, "part of an overall program of elite accumulation," and, as such, it did little to diminish dependency. ${ }^{76}$ "As long as foreign 
capital and technology remained the preferred means of economic development," writes Eghosa Osaghae, "indigenization could only mean a process that allowed the Nigerian capitalist class to work out more acceptable terms of 'compradorization' with its foreign benefactors." 77

In cinematic terms, it meant the attempted acquisition of a significant percentage of the box-office earnings of imported Hollywood films. It did not mean the establishment of a well-funded national film industry, despite the wishful efforts of some members of the Shagari administration to suggest that revenues from the exhibition of Hollywood blockbusters could reliably subsidize indigenous filmmaking. If anyone would benefit from indigenization's effects on film distribution and exhibition, it was Lebanese and Indian exhibitors, not all of whom were naturalized Nigerian citizens. Ultimately, however, AMPECA was able to receive a deferment, and finally a complete exemption from indigenization-another major policy failure.

It was amid the general confusions and embarrassments of indigenization that the Shagari administration, which came to power in 1979, simply seized all of the profits that had not yet been remitted to the Hollywood studios contracted to receive them (albeit via the flagrantly asymmetrical arrangements that AMPECA had been securing since 1962). When, as a direct response, the MPAA condemned Nigeria and urged member studios to pull out of the country, the association's actions seemed to confirm not just the bargaining failures of the Shagari administration but also Nigeria's extreme dependence on imports. As the economist J.F.E. Ohiorhenuan put it at the end of the 1980s, "the indigenization program merely consolidated and generalized the dependent insertion of the Nigerian economy into the international economy." ${ }^{78}$ The MPAA, which had been conducting a major antipiracy drive since 1975, managed to estimate monetary losses due to Shagari's indigenization measures (member studios were said to have missed out on a total of \$25 million), allowing it to put a number to an otherwise general sense of Nigerian corruption, which it nevertheless continued to invoke as a means of shaming a country deemed "treacherous."79

In the early 1980s, when the US Department of State began to issue "bold warnings about fraud in its advice to travelers and businesspeople contemplating visits to Nigeria," 80 the sordid story of Shagari's "theft" of Hollywood profits served as a useful distraction. It was, among other things, a means of deflecting from the fact that an American corporation, Stinnes Interoil, which had contracted with the Shagari administration to extract Nigerian oil and reimport refined petroleum products, owed Nigeria a whopping $\$ 157$ million. ${ }^{81}$ S.J. Timothy-Asobele has convincingly suggested that the MPAA was also seeking to publicly penalize Nigeria for the "downturn in fortunes" that immediately followed the oil boom-for, that is, an "economic predicament" that prevented local exhibitors from being able to afford Hollywood's persistently steep rental fees in a political-economic climate of near-complete dependence on oil revenues. ${ }^{82}$ 
Even as it emphasized Nigerian corruption, the 1984 Senate subcommittee cited the country's stubborn "promise":

Nigeria has long been at the forefront of Anglophone African states in the recognition of the rights of foreign authors and copyright owners through international agreements. ... Since 1962, Nigeria has adhered to the UCC [the Universal Copyright Convention, first adopted in Geneva, Switzerland, in 1952]. Unlike the case with other former colonies of the United Kingdom, Nigeria did not have the UCC extended to its territory by act of the colonial power. As a result, the United States has direct copyright relations with Nigeria. ${ }^{83}$

The language of diplomacy_of building and maintaining "good relations" —-was designed to suggest that Hollywood had been "misled" and "let down" by the suddenly "protectionist" Nigerian state. It was meant to distract from the ironic reality that, while preaching free-market fundamentalism, Hollywood had been employing "closed" tactics in Nigeria, all under the banner of "trade facilitation," which, as Yash Tandon puts it, is typically "exploited by the developed countries to pry open developing countries' economies under the excuse that they are 'simply' helping the developing countries to become more efficient in carrying out trade and getting integrated into the globalized market." ${ }^{4}$ The MPAA had even, upon the issuance of the Nigerian Enterprises Promotion Decree No. 4 in 1972, allowed AMPECA's name to eventually be changed to "the National Film Distribution Company (NFDC)." This was admittedly a merely superficial transformation (particularly considering the common practice of "fronting," or getting Nigerians to serve as smokescreens for foreign ownership), but one that required Hollywood's consent, and that therefore gives the lie to the MPAA's later claim that it was blindsided by indigenization efforts. ${ }^{85}$

"Let Nigerians distribute films!" proclaimed a correspondent for the Nigerian Daily Times in 1979, responding to the persistence of Hollywood domination even after the indigenization decree. ${ }^{86}$ Referring to the ongoing "Lebanisation [and] Indianisation of the Nigerian . . . motion picture industry in spite of the Indigenisation or Nigerianisation Decree of 1972," Timothy-Asobele pointed to the paradoxical heart of the matter. In permitting naturalized Nigerian citizens of Asian and Levantine descent to count as "indigenous," the decree had merely perpetuated Hollywood's stranglehold on the national market for motion pictures-the very cartelization that AMPECA had always epitomized. Foreign-born theater owners, newly classified as "indigenous," continued to sign affiliate contracts to exhibit films produced and distributed by the major Hollywood studios. ${ }^{87}$ In other instances, the Nigerian-born simply "fronted" for American expatriates who, thanks to this practice, retained effective control. ${ }^{88}$

As a result of the purportedly surprising actions of the Shagari administration, the Nigerian market was subjected to sanctions, a fairly familiar state of affairs by the early 1980s. The MPAA wanted Nigeria to demonstrate a renewed 
commitment to the neoliberal model at the very moment at which the federal government, in the guise of the ill-fated Second Republic, and however confusedly, was trying to alter some of the conditions of its participation in the world economy. "One way in which a government can make us withdraw is to change the rules of the game such that it is no longer commercial to be there," declared John Jennings, chairman of Shell, in 1997. "That hardly ever happens, but there is a perpetual tension-a natural tension-between the benefit to the investor and the government take." 89 Viewed in this light, the MPAA's sudden estrangement from Nigeria was merely symptomatic of the "perpetual tension" that Jennings describes-part of the naturalized "give and take" between foreign capital and the Nigerian government (whatever its composition at a given time).

Thus even as the MPAA imposed an embargo on Nigeria, US exports to the country were increasing by a factor of ten-an attempt to offset the trade deficit created by US reliance on Nigerian oil. Between 1989 and 1995-roughly speaking, the period of Nollywood's emergence-Nigeria was the dominant source of US net income from foreign investment in Africa south of the Sahara. In 1992, the year of Kenneth Nnebue's seminal Living in Bondage, US investment in the country generated $\$ 620$ million in net income, a figure that would grow to nearly $\$ 800$ million by $1995 .^{90}$ Despite this dramatic rise in private US investment in the Nigerian economy, the MPAA's annual Worldwide Anti-Piracy Newsletter, produced in collaboration with the Motion Picture Export Association (MPEA), reserved particular opprobrium for Nigeria during the Babangida regime (1985-93), citing Hollywood's many "difficulties" there..$^{91}$

Nigerian theater owners faced their own difficulties during this period-not least of all because the loss of Hollywood films meant the programming of more "third-rate" features from around the world. ${ }^{92}$ A less disputable factor, however, was the rise of moving-image alternatives to theatrical film. "Some people still prefer going to Cinema houses to enjoy watching films inspite [sic] of the popularity of Television and Video cassettes," claimed a Nigerian publication in 1985, though it conceded that, in Lagos, the "availability of video sets have [sic] reduced the patronage of cinema houses by the middle class." These theaters included a few fully air-conditioned facilities characterized by thrice-daily screenings and a steady supply of American films. ${ }^{93}$

Yet the death of theatrical exhibition seemed imminent. "The millennium," writes Jon Lewis, "promised a sort of cosmic spring-cleaning. Cinema loomed as a possible casualty. ${ }^{44}$ By the 1990s, however, Nollywood had arrived to offer alternative forms of production and consumption, lending substance to Lewis's claim that the decade marked "not the end of cinema but rather a transitional period from one new ... cinema to another." Such a transition was arguably more extreme, more decisive, in Nigeria than in the United States. Nollywood's pioneers had indeed established "new material conditions under which film history [could] persist." Lewis's watchwords ("flexibility," "resilience") well describe the industry's 
inaugural mettle, even if it was seen at the time as contributing to the obsolescence of theatrical film. "Declining patronage and intense competition from video films may push cinema houses [to close]," worried the African Concord in $1994 .{ }^{95}$ Nollywood was, however, arguably more symptom than cause of such dire conditions, and it would weather in its own ways the depredations of the Abacha regime. The industry's success, ironically enough, would establish some of the groundwork for the eventual return to Nigeria of commercial theatrical film, spotlighting the country as an indisputable media capital.

\section{THE MULTIPLEX ARRIVES- \\ AND HOLLYWOOD RETURNS}

In 2004, at the dawn of Nigeria's multiplex era, when crude oil prices hit record highs, the Office of the United States Trade Representative (USTR) reflected on the previous two decades, during which, the agency claimed, "almost no foreign feature films [were] distributed" in Nigeria and "movie theaters ceased to operate." Recognizing that conditions in the Nigerian market had "worsened dramatically" following the MPAA's withdrawal from the country, the USTR appeared to blame the MPAA's decision on a generalized Nigerian corruption, while simultaneously attempting to attract American investment in the newly revitalized "distribution and exhibition sector." ${ }^{26}$ Since 2016, the MPAA has consistently referred to New Nollywood (specifically, the exhibition on multiplex screens of big-budget Nigerian films) as representing "a stunning renaissance"-hyperbolic rhetoric meant to tout the emergence of innovation and entrepreneurship throughout the global South. ${ }^{97}$ The MPAA's sudden pro-Nigeria stance marks, of course, a major turnaround from its earlier pathologization of the country. By the early 1980s, the MPAA was aggrieved by more than just the (technically) illegal seizure of the assets of its member studios. Motivated by Shagari's failure to fulfill campaign promises-and, in particular, to raise the national minimum wage-the general strike of May 1981 directly affected film exhibition in Nigeria. Its participants included theater employees: grossly underpaid (and, in some cases, completely uncompensated) box-office attendants, ushers, and custodians, most of them from the air-conditioned cinemas of Lagos. Such participation undoubtedly led to a (further) decline in ticket sales.

The government's inability (or refusal) to prevent Indian and Lebanese theater owners from exploiting labor-even as it promised to enforce indigenization decrees-was one of many justifications for the strike. ${ }^{98}$ For its part, the MPAA has a long history of responding to foreign strikes by immediately suspending exports. The policy dates back at least to 1964, when the Motion Picture Export Association (MPEA), created by MPAA president Eric Johnston in 1945, banned exports to Mexico after workers in that country's film laboratories went on strike. In August 1964, the Mexican government had introduced a law requiring prints of imported 
films to be made in Mexican laboratories, at the expense of the films' distributors, who were accustomed to finding - and negotiating - better deals much closer to home. MPEA member companies immediately objected, and, in their aggressive efforts to invalidate the law, inspired workers to strike. As in the case of Nigeria nearly twenty years later, the MPAA imposed a ban on exports, citing "chaotic" and otherwise untenable local conditions, which would need to "improve" before the association's member studios could be expected to return to do business. ${ }^{99}$

In 1981, the MPAA swiftly banned all cinematic exports to Nigeria, worked with the U.S. Department of State, the World Intellectual Property Organization, and Interpol to facilitate the seizure of all Hollywood film prints that remained in the country, and, as Brian Larkin has pointed out, ensured the creation of vast infrastructures of piracy designed to fill the resulting cinematic gap. ${ }^{100}$ Ultimately, these pirate infrastructures-including vast cassette duplication factories (like Transerve, a massive facility established in Lagos in 1994)-would enable the emergence of the Nollywood industry, as equipment used to illicitly reproduce withheld Hollywood products was increasingly given over to content generated locally. ${ }^{101}$

The MPAA's exclusion of the Nigerian market lasted well past the country's disastrous adoption of structural adjustment programs in the mid-1980s, as cinemas-stripped of the ability to legally screen Hollywood films-were shuttered, urban crime surged, and Nigeria became an international pariah state amid the rise to power of Sani Abacha, whose dictatorship lasted from 1993 until 1998. The MPAA finally lifted the ban on exports to Nigeria after the return to civilian rule in 1999, but this was at best a symbolic gesture. There were no major, projection-ready movie houses left in the country-just a smattering of quasi-theatrical facilities equipped to screen the occasional Nollywood video for paying audiences, along with mobile cinema vans (complete with hooded screens for daytime projection) and the usual nontheatrical spaces like schools and churches. It was not until 2004, with the construction of the first multiplex in Nigeria (the Silverbird Galleria on swank Victoria Island), that the viability of the Nigerian market was fully restored in the eyes of the MPAA, which promptly authorized and carefully oversaw the distribution of Hollywood films to a Lagos that, in cinematic terms, seemed to be rebounding at a remarkable rate.

The balance of power between Lebanese and Nigerian theater owners finally began to shift in the latter's favor around 2004, when the Lagos City Mall, constructed in the Onikan district of Lagos Island, was launched by a Lebanese company that soon faced considerable financial difficulties. These threatened the mall's two theater screens, located in relatively small, side-by-side auditoria on the second of the mall's three floors. ${ }^{102}$ By the time the Silverbird Group, a Nigerian multinational conglomerate, opened its first galleria-complete with a state-ofthe-art multiplex occupying three floors of retail space-in May 2004, the Lebanese enterprise behind the Lagos City Mall was insolvent. It was forced to sell the mall to Ibukun Efuntayo \& Co., a Nigerian real estate company with deep roots 
on Lagos Island and a plan to indigenize the facility's retailers, including its twin exhibition spaces. The mall's cinema, like its restaurants and boutiques, struggled to attract customers over the next decade, owing to an array of factors, including the persistence of business arrangements with Lebanese distributors, which predated the sale of the mall and which precluded the exhibition of Nigerian films, even as competing theater chains, like Silverbird's, began to regularly offer such films in 2009. Thus the modest two-screen cinema at the Lagos City Mall continued to show relatively low-budget Indian and Chinese films even as its multiscreen counterparts came to rely on both Hollywood and New Nollywood "event" films.

Uncompetitive offerings were not the only elements stymieing the cinema at the Lagos City Mall, however. Onikan is hardly considered a prime retail location, and prices at the mall have never been appreciably lower than those on nearby Victoria Island, with its greater cachet and capacity to magnetize the affluent. In a desperate effort to keep pace with the Silverbird Galleria, the Lagos City Mall began a massive renovation and rebranding effort, attempting to transform itself into what its owners called "a lifestyle shopping destination"-a place to discover and acquire "trends and style." 103 In 2013, Ibukun Efuntayo \& Co. began buying out the leases of various retailers, aggressively advertising the newly vacant spaces in the hope of acquiring higher-end tenants. In June of that year, the mall's cinema, which had fallen into disrepair (and which had eliminated the vast majority of its employees in an effort to save money), was abruptly shut down, much to the chagrin of Lebanese distributors and local filmgoers alike-particularly those who had grown accustomed to the discount ticket and concession prices offered during the Christmas season. The following year, the mall's owners sold its cinema to the Genesis Group, a Nigerian conglomerate established in 1991. Initially focused on restaurants and hotels, the Genesis Group diversified into cinema in 2008, establishing Genesis Deluxe Cinemas (GDC), a theater chain whose corporate partners include Coca-Cola, Fidelity, LG, and Visa. Genesis Deluxe locations are known for their multimillion-naira escalators and lobbies that feature LG's OLED ${ }_{4} \mathrm{~K}$ TVs-flat and curved screens on which film trailers and Coke commercials tempt patrons to purchase tickets and concessions.

The Genesis Group is among Silverbird's chief competitors. In 2008, partly in response to the establishment of the Genesis chain, the Silverbird Group acquired the Ceddi Plaza Mall in Abuja. The following year, it opened the twelve-screen Silverbird Entertainment Center in that city. Ben Murray-Bruce, chairman of the Silverbird Group, called this "a retail revolution," adding, "A young Nigerian today would rather dress up and go to the mall than hang around in the market" - a sitespecific criticism of Old Nollywood, with its reliance on street vendors and its orientation toward home viewing. ${ }^{104}$ Yet this so-called "revolution" - the migration of big-screen cinema to the shopping mall-was well underway in the United States in the 1980s, when Nigeria's single-screen theaters began to close, one by one, until virtually none were left. In the latter country, as in the former, linking mall and 
movie theater would require massive investments and the participation of a wide range of players. Based in London, the private equity firm Actis backed the Persianas Group, a Nigerian real estate investment company with a plan to contribute to Murray-Bruce's "retail revolution." Founded in 1990 and headquartered on Victoria Island, the Persianas Group had, by the twenty-first century, turned its attentions to large-screen cinema. In 2005, with Actis' help, it began developing the seven-acre Palms Shopping Mall along the Lekki-Epe Expressway. South Africa's Shoprite, the largest food retailer on the continent, is an "anchor tenant," but the Palms Mall also boasts a six-screen multiplex operated by Genesis Deluxe Cinemas, which takes up the entire top floor. Rental income from the Genesis Group allowed Persianas to buy out Actis in 2008. To this day, the Palms Mall remains powerfully symbolic of the profitable return of theatrical film to the Nigeria from which the medium had once, for the most part, disappeared. ${ }^{105}$

\section{EXPERIMENTING WITH EXHIBITION}

By the start of the twenty-first century, some Nollywood filmmakers had begun to pursue theatrical exhibition in their own, idiosyncratic ways. Many of the firms involved in the New Nollywood movement have deep, precedent-setting roots in the industry, as well as crucial theatrical contacts throughout the United Kingdom. Located in Surulere, a middle-class neighborhood in Lagos, Klink Studios is one such establishment. Now a subsidiary of Kingsley Ogoro Productions (the company behind the Nollywood classic Osuofia in London [Kingsley Ogoro, 2003]), Klink was founded in the early 1990s, at the very birth of the Nollywood industry, primarily as an equipment-rental service. It continues to serve that function, having replaced its extensive stock of tape-based camcorders with an array of high-end digital recording devices. ${ }^{106}$

Like a number of other, similarly structured Nigerian rental companies, Klink regularly acquires equipment from the US-based Red Digital Cinema Camera Company at wholesale prices. For the production of the New Nollywood film The Mirror Boy (Obi Emelonye, 2011), Klink provided Red Cameras specially selected by Kingsley Ogoro, an indication of Ogoro's ambition to bridge the gap between Old and New Nollywood by serving as a creative guide and equipment expert. But it also offered expansive consulting services designed to maximize the film's chances of being booked in multiplexes both at home and abroad. Klink was, in fact, instrumental in the pre-sale of the film's exhibition rights to Odeon Cinemas and Empire Cinemas, two theater chains in the United Kingdom. (Odeon is owned by the American chain AMC Theatres, which is itself owned by the Chinese multinational conglomerate Wanda Group; Empire is owned by Irish entrepreneur Thomas Anderson.) Klink's relationship with Odeon Cinemas dates to 2007, when the rental company helped book the then-three-year-old Nollywood film Across the Niger (Izu Ojukwu, 2004) in Odeon's Leicester Square and Surrey Quays 
multiplexes, two of twenty-five Odeon locations in and around London. It thus established its credentials beyond the equipment-rental sector-specifically, as a new kind of Nigerian public relations firm capable of transforming Nollywood into a multiplex-friendly phenomenon, albeit with the considerable help of several corporate partners.

By 2007, Kingsley Ogoro was firmly in control of Klink Studios. As the producer of Across the Niger, he had good reason to want to revive the film, which had been only a modest moneymaker in traditional Nollywood markets-nothing like Ogoro's smash hit Osuofia in London, the rights to which were quickly sold to terrestrial and satellite television as well as to a range of international distributors, including internet companies. Ogoro had long understood the importance of ancillary markets, of expanding the commercial life of a film and wringing additional revenue from a variety of "release windows" (in the case of Osuofia in London, VCD and DVD followed by terrestrial and satellite broadcasting and, finally, internet distribution). Three years old in 2007, Across the Niger seemed the likeliest of Ogoro's films to receive a belated theatrical release. Unlike the wildly popular Osuofia in London, it was hardly omnipresent in media-rich African and diasporic communities, its relative scarcity such that people might actually be persuaded to go out and see it on the big screen. It is also a "serious", memorializing film-a combat drama set in 1967, at the outbreak of the Biafran Civil War. It could thus be marketed to diasporic audiences as a thoughtful meditation on their heritage, an educative take on African history, in alleged contrast to "typical" Nollywood entertainments.

In his efforts to bring Across the Niger to the multiplexes, Ogoro partnered with the Nigerian businessmen Christian Chukwudozie Udechukwu and Ben Etiaba, entrepreneurs and business-development experts with considerable experience in the United Kingdom. The two men run a limited London-based company called Business in Africa Events, which Udechukwu founded in 2002 as a sort of consultancy firm designed to facilitate the work of Africa-focused organizations in the UK. One such organization was the now-defunct FilmAFRICA (not to be confused with the Royal African Society's annual film festival, which was established in 2011, or with the Brooklyn Academy of Music's yearly partnership with the New York African Film Festival). The brainchild of Nigerian businessman Kene Mkparu, who served as its CEO before turning his attentions to FilmOne and FilmHouse, FilmAFRICA was a British festival without a home when Ogoro and Udechukwu crossed paths with Mkparu in London. The three men-along with a number of business experts from Klink Studios-formed a team that eventually succeeded in securing theatrical exhibition for Across the Niger under the banner of Mkparu's African film festival. Udechukwu, with his numerous connections, gained sponsorship from a host of Nigerian and British corporations, which essentially paid for the invitation-only premiere of Across the Niger in London's West End, at Odeon Cinemas' Leicester Square location. 
Establishing a major precedent for New Nollywood success, the Leicester Square premiere of Across the Niger was a glitzy red-carpet affair, complete with visiting Nollywood stars and various Nigerian dignitaries, along with live music and traditional dancing. While not, in itself, a moneymaker for Ogoro (since the five hundred tickets to the screening were provided free of charge to "VIPs"), it was instrumental in burnishing the film's "brand" and, ultimately, in persuading Odeon Cinemas - along with its rival, the London-based Cineworld, the secondlargest cinema operator in Europe-to book more Nollywood films as a way of appealing to African diasporic communities. In the process, Mkparu was hired by Odeon to help cultivate audiences for African films, an experience that would compel him to start his own theater chain in Nigeria, a response to the emergence of New Nollywood and, eventually, a major factor in its continued success.

Instructively, Ogoro's initial attempts to appeal to Odeon Cinemas hinged on the technical innovations of Across the Niger, which director Izu Ojukwu edited with then-new software (Microsoft's Windows Movie Maker) that gave his digital film the grainy look of well-worn celluloid. Highlighting Ojukwu's facility with a particular Microsoft product, Ogoro and his colleagues knowingly ran the risk of perpetuating Nollywood's association with a do-it-yourself amateurishness, given the relatively low cost and distinctly user-friendly dimensions of Windows Movie Maker, which requires no formal training and was in fact intended for consumers rather than industry professionals. But the efforts of Ogoro's team eventually paid off. Odeon Cinemas booked Across the Niger on the basis not merely of its marketable connections to Microsoft but also of its serious exploration of Nigerian history-of, specifically, the Biafran Civil War.

While very much an Old Nollywood production in its conception, and particularly in terms of its (scant) financing, Ojukwu's film nevertheless established some of the conditions of New Nollywood success. Chief among these was a readily definable - and thus widely exploitable-link to a major corporation and a narrative commitment to lofty matters far removed from the realm of witchcraft. Microsoft did not support the film's production in any formal capacity, but it clearly stood to benefit, however modestly, from the public relations value of a Nigerian feature film that had been edited with its software; Odeon Cinemas could reasonably expect a spike in ticket sales in the event of an acknowledgment from Microsoft (which, in this case, never came). A far more feasible strategy, and one that Odeon Cinemas actively embraced, was to book Across the Niger alongside Jeta Amata's The Amazing Grace (2006), a British-Nigerian co-production about the transatlantic slave trade and the moral awakening and spiritual conversion of John Newton, a slave-ship captain who became an abolitionist clergyman and the author of the eponymous hymn. Shot and distributed on $35 \mathrm{~mm}$ film, and starring a number of well-known British actors (including Nick Moran), The Amazing Grace was in fact designed for theatrical exhibition, and Odeon Cinemas booked it nearly one year after its Lagos premiere. The Odeon booking was a boon to 
the producers of The Amazing Grace, which was completed at a time when only a handful of multiplexes (most of them constructed in 2004) existed in Nigeria.

Amata's film was a decisive factor in what might be called the "multiplexification" of Nollywood. ${ }^{107}$ It was, in fact, the showpiece acquisition around which Odeon Cinemas booked an impressive lineup of Nigerian films in 2007, at the very moment of Nollywood's crisis of overproduction. ${ }^{108}$ Its rental arm stymied by the crisis (filmmakers who suddenly found themselves out of work were hardly in the market for cameras), Klink turned to novel business strategies and sources of revenue, building on the modest inroads that Ogoro had made in the UK market. With Amata securing a high-profile Odeon Cinemas release for The Amazing Grace, it seemed only logical to pursue theatrical opportunities for a few more "quality" films, chief among them Across the Niger, which had already made a splash (of sorts) in Leicester Square. Ojukwu's historical drama was the first Nollywood film that Odeon Cinemas booked to play alongside The Amazing Grace, though Odeon had previously flirted with Nollywood, as when it booked Obi Emelonye's clash-of-cultures comedy Lucky Joe in December 2006. This was thanks in part to corporate sponsorship, which Odeon required to cover some of its overhead costs (and as a supplement to concession-stand and ticket revenue), and which was secured from BEN Television, the "ethnic-serving" British satellite TV channel for which Emelonye has long served as head of production.

Nigerian multiplex operators like to trumpet their commitment to "local films" (in this case, New Nollywood blockbusters). They often claim to be sacrificing profits for the sake of supporting Nigerian movies, negotiating a split of box-office proceeds that purportedly favors Nollywood producers, in contrast to standard arrangements with Hollywood distributors, who typically receive up to 90 percent of a film's grosses, at least for the first couple of weeks of a film's run, after which exhibitors stand to receive an incrementally greater percentage of ticket revenue, or, as an alternative, incrementally lower rental costs. European theater chains like Odeon and Cineworld, however, are hardly in the business of charitably propping up Nollywood and instead set aside screens either for entirely corporate-sponsored affairs like the Leicester Square premiere of Across the Niger or for semi-traditional commercial runs. In both cases, the multiplexes require immediate compensation. For Nollywood's commercial (i.e., ticket-selling) runs, corporations and other sponsors agree to pay the likes of Odeon and Cineworld a substantial upfront fee, thus guaranteeing the exhibitors a minimum profit (in addition to coverage of some overhead costs) even in the event of a film's poor box-office performance.

While they clearly recognize the viability of the African diasporic market, European multiplex chains are still largely unwilling to gamble on Nollywood films, even when distributors are offering relatively low rental costs. Instead, they count on corporations (and even individual filmmakers) to cover fees that they impose in order to protect their interests against box-office failures. This is something that they do not do (and are in fact prevented from doing) with major 
Hollywood distributors, whose theatrical arrangements are far more formalized (as, for example, when the distributor and exhibitor are owned by the same parent company). Nollywood's poor reputation in the West-its association with "trashy" narratives, "bad" acting, and "shoddy" production values-is hard to shake. When European theater chains treat Nollywood accordingly, keeping even the industry's most expensive, artfully made films at arm's length, the consequences are, however, far from simple. What some may see as a clear example of the ongoing marginalization or "ghettoization" of Nollywood on the global stage, others may interpret as a sign of Nollywood's respectability. After all, no less illustrious a British multinational corporation than Richard Branson's Virgin Group was one of the funders of the Nollywood film festival that Odeon hosted throughout the fall of 2007-a considerable coup for Nollywood, and one that was widely touted throughout Nigeria.

In some cases, corporate sponsorship was needed not merely to pay multiplex chains but also to subsidize the striking of new film prints and their distribution to various locations in and around London. In the case of Across the Niger, however, Klink Studios itself covered the cost of converting Ojukwu's digital film to celluloid, producing a handful of $35 \mathrm{~mm}$ prints in London. It thereby established the importance of celluloid as a prerequisite for entrée into the theatrical sector at a time when few exhibitors, in London or elsewhere, were equipped with digital projection systems. If several New Nollywood filmmakers (Ojukwu included) are, by now, firmly committed to celluloid production, it may well be out of more than mere nostalgia; it may be because they remember or have heard about the headaches that Klink faced in converting Ojukwu's master disc into a few multiplex-ready $35 \mathrm{~mm}$ prints. (It is unclear just how much money Klink lost in the process, although corporate sponsorship and the sale of broadcast and streaming rights allowed it to absorb at least some of its losses.) But many filmmakers also know that there are diminishing opportunities for celluloid projection in commercial cinemas around the world. Most American multiplexes made the conversion from celluloid to digital projection by 2012, when, for the first time in the history of American film exhibition, digital projection technologies outnumbered their analog counterparts. But some theaters-particularly small, independent cinemas, along with museums - have resisted dispensing with celluloid projection, and it is to these venues that New Nollywood often strategically appeals, with directors like Ojukwu and Kunle Afolayan presenting their $16 \mathrm{~mm}$ and $35 \mathrm{~mm}$ films as rare "events" (as indeed they are in the digital age). Ojukwu ran into trouble, however, when preparing for the New York premiere of his New Nollywood film '76 (2016). Not only was he increasingly unable to protect his $16 \mathrm{~mm}$ prints from being destroyed by airport security (whose detection equipment is notoriously unfriendly to celluloid), but he also discovered that Columbia University, which was set to host the first screening of ' 76 , would not, in fact, be able to project in the director's preferred format. The ever-resourceful Ojukwu, however, arrived at the premiere armed with a rough cut on DVD. 
When Ojukwu's Across the Niger, newly converted to $35 \mathrm{~mm}$ film, began its brief commercial run at Odeon Cinemas nearly a decade earlier, it was on a single screen in the sprawling Surrey Quays Shopping Centre in southeast London, which caters to a large African diasporic population. It was soon joined by a number of Nollywood films that had similarly made the dramatic, virtually unprecedented jump from VHS and VCD to $35 \mathrm{~mm}$ film. Earlier efforts to bring Nollywood to the big screen were less examples of material conversion-of Nollywood's transformation into a new format, a new medium - than of a simple scale adjustment. When, in February 1997, Daar Communications rented ten Lagos facilities for the exhibition of Domitilla: The Story of a Prostitute (Zeb Ejiro, 1996), it also rented video projectors from Klink and other outlets, thus obviating the need to convert the VHS master to $35 \mathrm{~mm}$ film. This was a move that, ten years later, would not be an option for Odeon Cinemas, given the theater chain's lofty brand and its relatively high ticket prices (which it was unwilling to reduce for Nigerian imports). The considerable loss of resolution that resulted for Domitilla was simply not something that Odeon was willing or even able to risk with Across the Niger and other Nollywood films. By the fall of 2007 , the latter-Odeon's large-screen offeringsincluded Kunle Afolayan's directorial debut, Irapada (2006), a Yoruba-language thriller; Emelonye's aforementioned Lucky Joe (2006), which follows the quirky adventures of a pair of urban misfits who encounter official corruption; Kingsley Omoife and Richard Mofe-Damijo's State of the Heart (2007), a romantic drama costarring Mofe-Damijo and Stella Damasus; Aguila Njamah's Heartbeats (2006), a production of Emem Isong's Royal Arts Academy; Henry Omereonye's Felicima: One Gift (2007), starring Nollywood superstar Genevieve Nnaji as a high-powered public relations executive whose encounter with a disabled beggar changes her life; Stephanie Okereke's Through the Glass (2007), a romantic comedy that Okereke shot in California after earning a master's degree at the New York Film Academy; and Ojukwu's own Images of Another Day (2007), an omnibus film produced by the legendary Amaka Igwe and based on the lives of four "street children" (one of whom, a ten-year-old girl, is forced into a marriage with a fifty-five-year-old man). Odeon screened one of the ten films per weekend for ten consecutive weekendsfrom Friday, October 19 until Sunday, December 23. (Across the Niger was the first, and Through the Glass the last; in between, The Amazing Grace, which had played earlier in the year, was "revived” for three days.) Odeon's Surrey Quays location was not the only exhibition site for these films, nor was its special "Nollywood Season" (as the ten weeks in 2007 came to be known) the only time the theater chain embraced them. Lucky Joe had gone into general release a year earlier, when it played in three Odeon locations (Surrey Quays, West Thurrock, and Manchester) and three Cineworld locations (Staples Corner, Wood Green, and Wandsworth). With the Nollywood Season, Odeon was testing the viability of maintaining a relatively steady supply of Nigerian films in at least one of its locations, although it was clear that, whatever the results might be, the theater chain was not going to give up its demands for upfront compensation. It continued to require payment 
from distributors, forcing them into the awkward, untenable position of having to subsidize more than just the striking and shipping of prints, and perpetuating Nollywood's lowly associations by transforming it into, essentially, a pay-to-screen enterprise. ${ }^{109}$

All of the abovementioned films ultimately benefited from exhibition in Odeon Cinemas, however, although not because they became box-office hitsthey didn't and couldn't, given only a handful of showtimes. Their theatrical runs instead managed to boost consumer interest, particularly in Nigeria, where theatrical opportunities have always been scarce, but where the cachet of a London exhibition can easily be exploited, as long as the pay-to-screen phenomenon is strategically omitted from the equation. Odeon conferred upon these films a certain glamor and prestige, practically guaranteeing that they could earn revenue from ancillary or "downstream" markets. Indeed, those markets quickly presented themselves, proving the importance of theatrical exhibition even for films that stand little chance of becoming bona fide box-office smashes. Odeon's Nollywood films may not have sold many tickets (comparatively speaking), and they were hardly eagerly sought by the multiplex chain. Again, their exhibition had to be subsidized, in large part, by nine corporate partners, from Nigeria's Oceanic Bank to BEN Television, the British TV channel that caters to expatriate Africans. But they all received subsequent DVD releases and were later licensed to pay TV, free $\mathrm{TV}$, and various streaming and video-on-demand platforms, which might not have happened in the absence of an eminently marketable Odeon run. As Tino Balio points out in his account of Hollywood in the twenty-first century, "A theatrical run, no matter how brief, gives a picture cachet that helps sales in foreign and ancillary markets." 110

The "movement through markets" of the abovementioned films was in decidedly eccentric directions, however, destabilizing conventional links between foreign and domestic sectors, as well as between "traditional" and ancillary windows. Many of these films, including Lucky Joe and State of the Heart, began their commercial lives not in Nigeria-their country of origin-but in the United Kingdom. This initial market proved, in nearly all of these cases, to be a minor one in terms of revenue, serving merely to whet the appetites of Nigerian and diasporic consumers and setting the stage for profitable sales to television networks and, eventually, internet companies. The American film producer James Schamus notes,

For the vast majority of films an exhibition run in cinemas is simply an advertising campaign that lends an aura of cinematic legitimacy to the "back end" ancillary exploitation of the film on various forms of television and other media-video rental and sales, pay and basic cable, broadcast television and satellite transmission, airplane and cruise ship projection. This 'back end' long ago became the front end in terms of financing and ultimate revenues. ${ }^{111}$

Schamus is, of course, describing domestic markets in the United States, but his comments certainly apply to the New Nollywood movement, in which breaking 
even is difficult with theatrical exhibition alone. Indeed, all of the elements of the "back end" that Schamus enumerates, with the exception of cruise-ship projection, are major revenue streams for New Nollywood producers.

Nigerian films have been staples of some in-flight entertainment packagesincluding on major airlines, like British Airways and United-since as early as 2012. Dozens of films, from Old Nollywood melodramas to the latest hits, are often bundled and sold to airlines by distribution companies that serve the inflight market, and that acquire Nollywood content not from its producers but from the London-based video-on-demand service African Movie Channel (AMC) and, increasingly, iROKOtv, whose licensing arrangements give them the right to "resell" Nollywood films to third-party distributors. ${ }^{112}$ This is merely one of many examples of how ancillary markets are exploited without the cooperation of Nollywood producers and in ways that do not necessarily financially benefit them. For while in-flight platforms have long been cited as key sources of additional exposure for Hollywood blockbusters-ways of promoting DVD sales and other profits from "ancillary audiences"-this is hardly the case for Nollywood films anonymously packaged and ported to in-flight channels whose names typically centralize the word "African," offering no distinctions between, say, Nigerian and Ghanaian content, much less any identifying information about the films in question, beyond what may appear in the opening and closing credits (which are, in any case, often excised). ${ }^{113}$ Major Hollywood films like Wonder Woman (Patty Jenkins, 2017) and Spider-Man: Homecoming (Jon Watts, 2017) are, in contrast, routinely highlighted on the pages of in-flight magazines and on airline websites.

New Nollywood has lately exhibited a strategic orientation toward in-flight entertainment, its high-end offerings steadily becoming what Antoine Compagnon, writing about contemporary French cinema, derisively referred to as "the type of films Air France shows to its captive passengers." 114 In 2016, Air France sponsored the world premiere of Kunle Afolayan's thriller The CEO on one of its flights from Lagos to Paris. Once on the ground in France, the film was screened theatrically at NollywoodWeek, a festival in Paris that purports to offer "Nollywood at its best." It then made its way back to Nigeria for a gala screening at Eko Hotels and Suites, a five-star resort and conference center in Lagos, which has long hosted star-studded red-carpet premieres of Nollywood films. (Eko is the largest hotel in Nigeria and among the facilities capable of accommodating the crush of stars, producers, directors, publicists, friends, family members, and fans characteristic of Nollywood film premieres; it was designed during the oil boom of the 1970s, partly as a meeting place for international oil executives and their retinues.) A private screening of The CEO was later held at the Toronto International Film Festival, and, in October, the film began its brief run in London, at Vue Cinemas' Leicester Square location, following the earlier pattern established by Kingsley Ogoro, Kene Mkparu, and their associates. In the case of The CEO, Air France covered Vue Cinemas' fees in exchange for the right to advertise there, 
at least for the duration of the film's run. The Air France and SkyTeam logos were omnipresent at the October 27 th premiere, which was ironically bathed not in the green and white of the Nigerian flag but in the red, white, and blue of the French airline, despite the fact that the event was timed, like most Nollywood premieres in the UK, to coincide with the month of Nigerian independence.

None of these exhibition opportunities were profitable for Afolayan-not, that is, in the short term. Most were nonprofit, invitation-only events, with the conspicuous exception of the film's exhibition at Vue Cinemas, which charged a relatively steep $£_{30}$ per ticket for the gala premiere, a price that it lowered by about two-thirds for subsequent screenings (of which there weren't many, just a smattering of showtimes in late October 2016). Theatrical exhibition thus remains largely symbolic, in the sense described by Balio and Schamus-an exciting, eyecatching way of lending legitimacy to films that would, perhaps, otherwise seem substandard, quasi-cinematic products. That such products need the big screen's imprimatur is evident from the growing number of Nollywood producers attuned to Murray-Bruce's "retail revolution," eager to have their work experienced in the kind of projection sites that had largely disappeared from Nigeria by the late 1990 .

The corporate strategy of transnational co-partnering has enabled a small number of Nigerian businesses to corner the national theatrical market, committing their screens to favored Hollywood and local distributors and leaving little to no room for independents. FilmHouse, for instance, became the largest theater chain in Nigeria by partnering with Fox and the IMAX Corporation, whose press releases have consistently touted the most populous country on the African continent in rhetoric borrowed almost verbatim from Eric Johnston. ${ }^{115}$ In 2012, IMAX classified Nigeria as an "underpenetrated market" eminently capable of boosting Hollywood's global revenues. ${ }^{116}$

The corporation's targeting of the country is consistent with what Charlie Keil has called "the IMAX intervention," an aggressive program of international expansion initiated toward the end of the 1990s. IMAX, writes Keil, "insinuat[es] itself into the arena of international exhibition by defining itself apart from conventional practice," promoting and imposing its "distinct projection technology", a proprietary package that is then identified with select multiplex chains like FilmHouse. ${ }^{117}$ Calling the IMAX-FilmHouse partnership "a strategic move," Andrew Cripps, the president of IMAX's operations in Europe, the Middle East, and Africa, stressed the size of Nigeria's population in terms that echoed Johnston's postwar bombast. ${ }^{118}$ In Johnston's day, the major studios, long accustomed to cartelization, had pursued their shared commercial interests by partnering with Lebanese exhibitors in an effort to secure the Nigerian theatrical market, encouraging the importation of Hollywood films from agents based in the UK as well as from exhibitors in Ghana. Beginning in 1959, the latter were authorized by the Ghanaian government to "bring in as many United States films as their dollars [could] buy"-a quota system that, by the early 1960s, had "not proved burdensome to United States film distributors," in the wry words of the MPEA. ${ }^{119}$ 


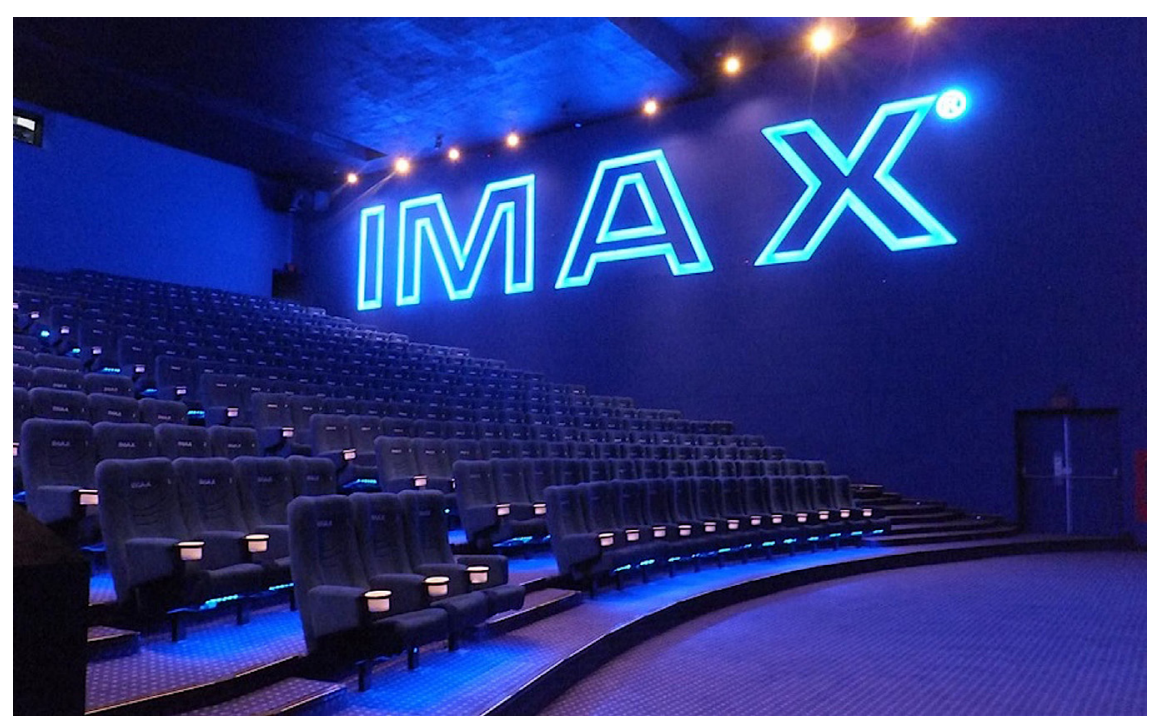

FIGURE 24. The IMAX brand has come to dominate Nigeria's theatrical landscape, as at FilmHouse Lekki, with its "true" IMAX screen. Photograph by the author.

Throughout the "Development Decade" that followed independence, AMPECA representatives and other "experts" were among the technocrat-guardians in charge of attending to the Nigerian media sector. ${ }^{120}$ To this day, the Nigerian state remains invested not in the enactment of media policy via democratically elected leaders responsive to their diverse constituents, but rather in the identification of new groups of technocrat-guardians deemed capable of "correcting" Nollywood's alleged tendency toward corruption, overproduction, and other evils said to be generative of global anti-Nigerian stereotypes (which, as active constraints on potentially lucrative forms of tourism, are plainly "bad for business"). In the spring of 2012, Nigeria's Ministry of Information presented the Motion Picture Practitioners Council of Nigeria (MOPICON) bill, which had been circulating in draft form since 2006, to the Federal Executive Council. The bill, which sought to "establish an overarching regulatory framework for filmmakers in Nigeria in line with best practices, with the objective of streamlining production procedures," was among the most heavily publicized of recent efforts to attract Hollywood capital by “improving” Nollywood's image. ${ }^{121}$

In 2013, the Jos-based Nigerian Film Corporation, which continues to serve (however inadequately) as the government's agency for film development and promotion, backed MOPICON as a means of (further) integrating Nollywood into Hollywood's global political economy, maintaining that "passage of the bill would likely result in a considerable uptick in foreign investment in Nollywood." 122 As a state-initiated inquiry into filmmaking, MOPICON was meant to break the power of Nollywood's allegedly "backward" marketers and to ensure that other, 
“worthier" parties would serve a gatekeeping function, "screening out" potentially "undesirable" aspiring filmmakers-precisely those "amateurs" allegedly incapable of appealing to the likes of IMAX and Netflix. MOPICON was therefore rooted in elitist anxieties regarding the ease with which some Nigerians appear to enter the Nollywood industry. Its commitment was clearly to Nollywood's cosmopolitan potential, and not to its local popularity. After all, low-budget Asaba films-full of Pidgin, "bush" humor, and other signifiers of Africanity suspected of estranging Hollywood-have always flourished in the face of state-sponsored elitism.

Whatever the motivations behind it, the now-dead MOPICON was far from the first attempt to regulate film production and distribution in Nigeria. Those committed to "rehabilitating Nigeria's international standing" in the immediate aftermath of military rule were hardly unconcerned with cinema-that is, hardly inattentive to Hollywood as a potential source of direct investment. ${ }^{123}$ By 2011, the World Bank was pledging \$5 million to the Nigerian Film Institute to build a studio, increase and enhance the training of personnel, and, perhaps most significantly, support the establishment of a facility for the leasing of equipment directly from multinationals, rather than from Nigerian intermediaries like Klink Studios and the Hub Media Store (located in the aforementioned Palms Mall). Couching equipment leasing as altogether necessary in an era in which "new cameras and software change with increasing rapidity," the World Bank promoted the further integration of Nigerian filmmakers into the world economy, insisting on the "availability" of foreign manufacturers able to partner with "local stakeholders" to whom they could rent their state-of-the-art products and services. ${ }^{124}$ But Nollywood filmmakers have been doing this for a long time and without World Bank support, as the case of Klink Studios makes clear.

The World Bank's interest in what it envisioned as "Studio Nollywood" ("Creating a professional studio that caters to Nigerian filmmakers would go a long way to improving standards," it announced) occasioned precisely the sort of language that has long been employed in order to strategically obscure the foreign interests that are necessarily served via such a "catering" process. Over fifty years prior, Lloyd Young exploited this rhetoric of "assistance" in introducing his plan to "help" the Eastern Region develop a Hollywood-style "movie colony" (the imaginative antecedent of the World Bank's "Studio Nollywood"), the only observable consequence of which was the production in Nigeria of Young's film The Mark of the Hawk. Emphasizing the alleged amateurishness of Nollywood's efforts-insisting that the industry desperately needs the helping hand and capital investment of the foreign "expert" - is a convenient means of secreting corporate efforts to target not only Nigerian cultural production but also individual Nigerian consumers. "Although Nigeria's filmmakers are extremely inventive and capable of improvising to overcome any situation," asserts the World Bank, "they will not be able to move up the value chain without increased formal-sector training." 125 The message is clear: submit to Hollywood capital, or stagnate in its absence. 
Emphasizing "the financial benefits of a cinema release," the World Bank has gestured toward the importance of "enabling" theatrical distribution for local productions. But its plan to "establish a venture capital facility for the [Nigerian] entertainment industry on a commercial basis" reads as just another initiative to "open up" Nigeria to foreign interests. In this sense, it is reminiscent not simply of Lloyd Young's late-colonial initiative. It also recalls AMPECA's post-independence efforts and other strategies for exploiting the Nigerian market in the name of Hollywood capital. ${ }^{126}$

In 2004, the year the first multiplex opened in Nigeria, the Office of the United States Trade Representative assured potential Hollywood investors that "there are no [Nigerian] trade restrictions that discriminate against the United States." ${ }^{127}$ Prior to and even in the wake of the MPAA ban (when Muhammadu Buhari, imprisoning scores of trade unionists, was widely seen as "reversing" Shagari's "errors," despite his resistance to structural adjustment and other externally imposed market reforms), Hollywood studios were well aware of this reality, their interests vigorously defended by the MPEA, whose purpose was to eliminate and preempt all manner of trade restrictions. Today, many of the same studios participate in asymmetrical relationships with the Nigerian-owned multiplex chains that guarantee screens for their films. Hollywood distributors have long enjoyed pricing power in Nigeria, as when they ratcheted up rental fees during the oil boom, swiftly withdrawing their business when the boom went bust and exhibitors could no longer afford to pay the extortionate premiums. Lasting from the early 1980 os until the late 1990s, Hollywood's relative estrangement from Nigeria would, at first glance, appear to suggest the expendability of the Nigerian market-the capacity of the American film industry to survive and even thrive without it. But it was, in part, the fear of Nigeria's population size that motivated this retreat. In banning exports to the country, the MPAA cited not Nigeria's disposable status but, rather, its awesome power, inextricable from an expansive consumer base capable of doing great damage to the American film industry through the theft of film prints and other illegal practices presented as prototypically Nigerian.

When, in 1998, culture ministers from twenty countries met in Ottawa "to discuss how they could 'build some ground rules' to protect their cultural fare from 'the Hollywood juggernaut," Nigerians were not among them. ${ }^{128}$ This absence contrasted sharply with Nigeria's prominent role, two decades earlier, in the efforts of "Third World" nations to outline, via UNESCO, a New World Information and Communication Order (NWICO). The movement may have been "impaled on the sword of neoliberalism wielded by the United States and Britain" (both of which would withdraw from UNESCO in the 1980s). But it clearly signaled the activist orientation of the Mohammed/Obasanjo regime, with its stated interest in restructuring the IMF, the World Bank, and GATT. ${ }^{129}$ Charles R. Acland writes, "It is not hyperbole to suggest that we continue to live in the shadow of decisions made by the Reagan Justice Department"-decisions whose underlying logic was 
swiftly "exported as the 'unavoidable' conditions of globalization." ${ }^{30}$ The shadows currently cast on the landscape of commercial theatrical exhibition in Nigeria have even older sources-among them the post-independence efforts of AMPECA to secure the national market.

IMAX's particular expansion policy led the corporation, perhaps inevitably, to Nigeria, where it has helped establish the viability of various projection sites. Yet as Keil points out, IMAX's "possession of a salable/marketable technology could easily override the national/regional base of a theater chain's ownership."131 If IMAX, a Canadian company based in Ontario but closely associated with Hollywood features (as in its exclusive showing of Disney's Fantasia 2000 at the start of the new millennium), has helped secure the survival of theatrical film projection around the world, including in Nigeria, it has just as surely played a part in the obsolescence of the concept of national cinema. Just how much of an "indigenous victory" is Murray-Bruce's "retail revolution" when brand names like IMAX and Coca-Cola saturate the field of film exhibition in Nigeria today? Large-screen cinema may have returned to the country in the twenty-first century, but at what cost?

The following chapter considers these questions in some detail, tracing the emergence and development of the multiplexes in Nigeria. In his account of contemporary India, Nitin Govil argues that, since the turn of the twenty-first century, "the multiplex has assumed a prominent place in the Indian theatrical landscape, transforming film production and distribution." Citing "the new economic cultures of corporatization and multinational investment" as both drivers and beneficiaries of the multiplex revolution, Govil suggests that oligopoly conditions are inevitable. All over the world, multiplex cinema is "dominated by a handful of companies positioned to benefit from international investment." "The multiplex theater," Govil maintains, "has become both a monument and a portal to the world of conspicuous consumption in late modern India," and the same can surely be said of its presence in post-Abacha Nigeria. "Multiplexes are 'abstract' spaces that facilitate and imagine consumer mobility with global commodity culture," writes Govil. ${ }^{132}$ In Nigeria today, they are nothing less than the symbols of cinema's rebirth-projection sites that have made possible the return of theatrical film. 